\title{
Depositional Environment of the Devonian Quartz Sandstones in the Bāle Sand Pits
}

\author{
Daiga Blāķe ${ }^{1}$, Kristīne Tovmasjana ${ }^{2}$, Ģirts Stinkulis ${ }^{3},{ }^{1 ; 3}$ University of Latvia, ${ }^{2}$ UNESCO
}

\begin{abstract}
This paper summarises data about the depositional environment of Devonian quartz sandstones in Latvia and discusses new fieldwork data from Bāle 1 and Bāle 2 sand pits. The commercial bed in these sand pits is composed of fine to gravel size grained white and pale gray sandstones with mud clasts and quartz pebbles in places.

Studies in Bāle sand pit sectors 1 and 2 suggest the deposition of sediments in details channel and sand bars, with the scarce influence of tidal processes on sedimentation.
\end{abstract}

Keywords: Sietiņi Formation, Latvia, deltaic sedimentary environment.

\section{INTRODUCTION}

Devonian quartz sands are one of the most valuable local mineral resources, which can be used for glass, glass fiber, casting sand and other production. Unfortunately it hasn't been acquired in the most effective way in the last years. Devonian quartz sands in Latvia are represented by the Middle Devonian Gauja Regional Stage (RS) deposits. There have been several large-scale studies dealing with the composition, structure and sedimentary environment of the Middle Devonian Gauja RS quartz sand deposits. The most detailed of them are studies by V. Kuršs [1;2] and Pontén, PlinkBjörklund [3;4]. Most recent studies by A. Pontén and P. Plink-Björklund [3;4] suggest that these quartz sands accumulated in the tide-influenced delta plain, are different from delta front and shallow sea environment as it was assumed before by V. Kuršs [1;2]. The aim of this paper is to interpret the depositional environment of the Devonian quartz sandstones in Bāle sand pits according to fieldwork data and to summarize the results of previous studies. It is important to note that the Devonian sandy deposits traditionally have been called poorly consolidated sandstones in sedimentological literature [1;2], but attributed to sands in mineral deposit research [5]. Therefore in this paper the deposits are called either sands or sandstones according to the context,

\section{DISTRIBUTION AND COMPOSITION OF THE DEVONIAN QUARTZ SAND DEPOSITS IN LATVIA}

Red and yellow colored Devonian sandstones, which occur frequently in outcrops along rivers in $\mathrm{N}$ and NE Latvia, are not suitable for exploitation with the exception for use as a source for drinking water due to a high amount of iron compounds and other harmful admixtures. This is the reason why only white or pale gray sandstones with small amount of coloring iron oxides are possibly of good economic value and can be used for glass production.
Devonian white and pale gray quartz sands are present only in a specific part of the stratigraphic succession, which corresponds to the Middle and Upper Devonian boundary deposits including the Gauja and the Amata

RS. Practical value of the Amata RS quartz sands is not significant, but these deposits have been exploited historically in the 17th and 18th Century near Kuldīga [5].

Deposits of the Gauja RS in the north-eastern Latvia (along the Riga-Pskov fault zone) have been divided into two formations (Fm): the lower part is the Sietini Fm (Fig.1; Fig. 2) consisting mostly of fine to coarse-grained white sandstones, and the upper clayey part is the Lode Fm composed of siltstones, claystones and very fine-grained red sandstones [1]. The Sietini Fm is composed of relatively coarse-grained sandstone in places rich in gravel and even quartz pebbles, up to $3 \mathrm{~cm}$ large. These quartzose sandstones clearly differ from their age-equivalent yellow and reddish sandstones of the lower part of the Gauja Fm by light grey colour and high maturity [6]. Difference in lithology, fossils, clay mineralogy and composition of the heavy mineral fraction is the reason why the Gauja RS has been divided in the Lode and Sietini formations in the north-eastern Latvia [7].

Quartz sands (quartzose sandstones) of good economic value in Latvia are present in the Middle Devonian Gauja RS Sietini Formation (Fm) which is located in the northern and north-eastern Latvia. Smaller amount of quartz sands are present also in the Jurassic alluvial deposits, which are distributed in the western Latvia [5]. As this paper is focused on the quartz sands with economic value present in the Devonian deposits, further the distribution and composition of only Sietini Fm will be discussed.

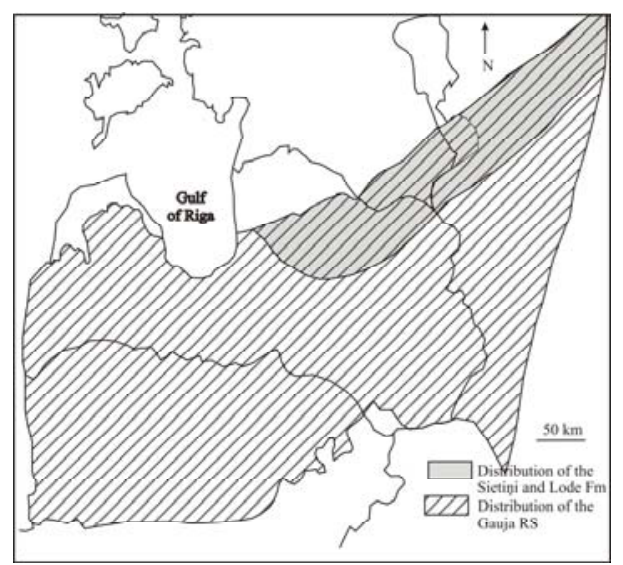

Fig. 1. Scheme of distribution of the Middle Devonian Gauja Regional Stage and Sietini Formation [3]. 


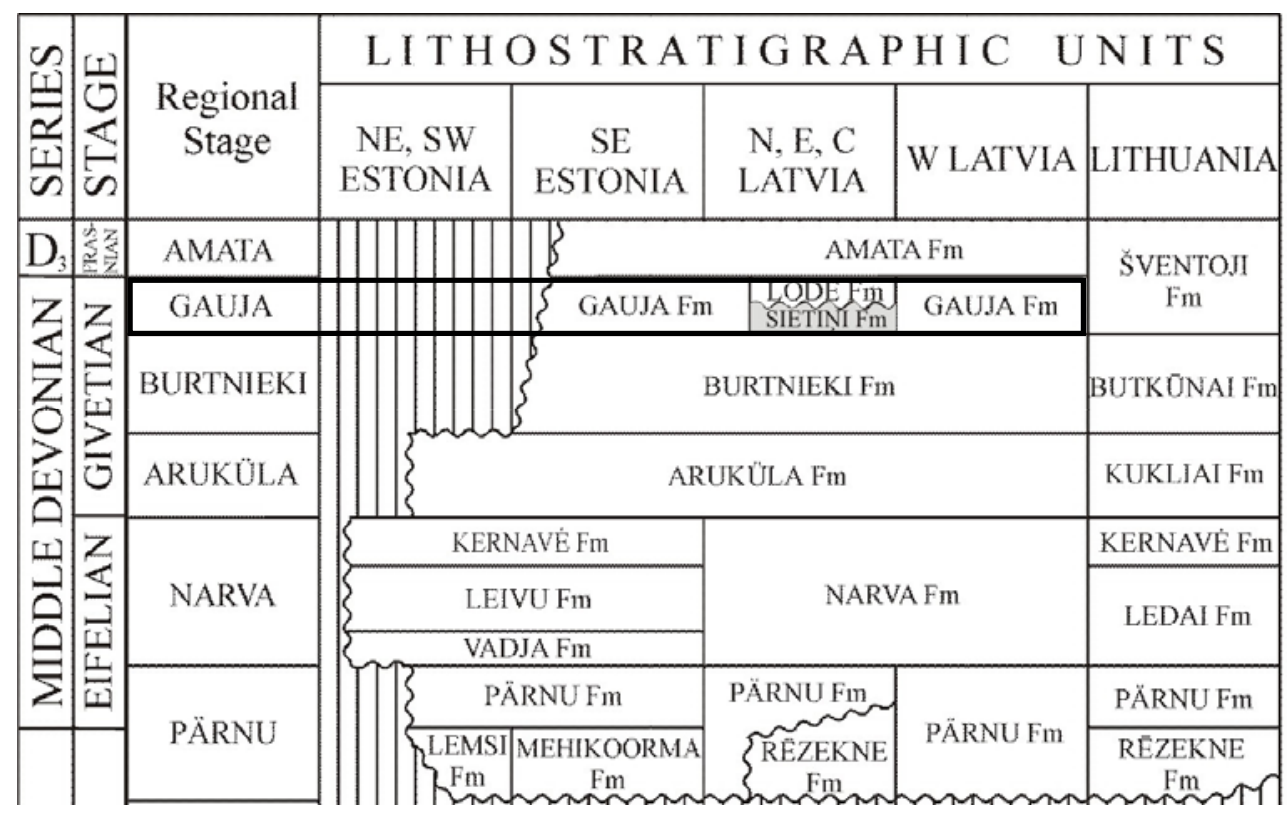

Fig. 2. Location of the Gauja Formation and Sietini Formation in the stratigraphic chart in the Baltic States [8].

The mineral composition of sandy and clayey deposits of the Gauja RS varies from west to east and has been used as another criterion to divide the Sietini and Lode formations in north-eastern Latvia. The light fraction of sandstones in the western and central part of the Baltic States (Gauja Formation) is predominated by quartz, but the content of feldspars, which are medium resistant in weathering processes, is also quite high (up to $10-15 \%$ of total mass). Micas occur too. Heavy fraction consists of zircon, tourmaline and staurolite together with minerals medium resistant to chemical weathering garnets and apatite. In the north-eastern Latvia and further to the east the sandstones contain a highly mature mineral assemblage - quartz with a slight admixture of feldspars and micas in the light fraction, and mostly zircon, tourmaline and staurolite in the heavy fraction [1]. Chemical analyses of quartz sands have been performed during geological exploration works, and results of these analyses have been published [5]. The average content of quartz in sandstones is $77-92.5 \%$. These highly mature light gray and white sandstones are present in the Sietini Fm and as they usually are weekly to medium cemented can be used as quartz sands and have been extracted in sand pits. The quartz sands of the Sietini Fm were exploited in Bāle deposit, sector 1, Straupnieki deposit, and currently are mined in Bāle deposit, sector 2. In general up to $97 \%$ of the total mass of the Devonian quartz sand consists of $\mathrm{SiO}_{2}$ and admixture of $\mathrm{Fe}_{2} \mathrm{O}_{3}$ reaches 0.16$0.17 \%$ (Table $1 ;[5]$ ). According to previous studies, using enrichment of quartz sands, $98 \%$ of $\mathrm{SiO}_{2}$ can be reached and the amount of $\mathrm{Fe}_{2} \mathrm{O}_{3}$ can be reduced till $0.03 \%$ [1]. V. Kuršs [2] suggests that the highly mature quartzose sandstones of the Sietini Fm are composed of clastic material transported from the source area (eastern part of the Baltic Shield) where chemical weathering crust developed during the Devonian Period.
TABLE I

COMPOSITION OF QUARTZ SANDS OF THE SIETIN̦I FORMATION [5]

\begin{tabular}{|l|c|c|c|c|c|c|c|}
\hline & \multicolumn{3}{|c|}{$\begin{array}{c}\text { Content of main } \\
\text { fractions, mass \% }\end{array}$} & \multicolumn{3}{c|}{ Chemical composition, mass \% } \\
\hline \multirow{2}{*}{ Sand pit } & $\begin{array}{c}>0.5 \\
\mathrm{~mm}\end{array}$ & $\begin{array}{c}0.5- \\
0,1 \mathrm{~mm}\end{array}$ & $\begin{array}{c}<0.1 \\
\mathrm{~mm}\end{array}$ & $\mathrm{SiO}_{2}$ & $\mathrm{Al}_{2} \mathrm{O}_{3}$ & $\mathrm{Fe}_{2} \mathrm{O}_{3}$ & $\mathrm{TiO}_{2}$ \\
\hline Bāle & 5.6 & 88.9 & 5.5 & 99.66 & 0.73 & 0.19 & 0.07 \\
\hline Bērziṇi & 6.5 & 86.9 & 7.8 & 98.07 & 0.59 & 0.17 & 0.14 \\
\hline Cīruḷi & 11.5 & 80.7 & 7.8 & 97.24 & 1.07 & 0.31 & - \\
\hline
\end{tabular}

\section{MATERIALS AND METHODS}

During this study data from literature and field work data about the composition and depositional environment of the Sietini Fm have been summarized.

In order to precise the composition and depositional environment of the quartz sandstone deposits the field studies were made in the Bāle sand pit sectors 1 and 2 (Fig. 3). Sector 1 of the Bāle sand pit has been already closed down for years and flooded, but sector 2 is still under exploitation being used only in the last 10 years.

Eight outcrop walls representing Sietini Fm in the Bāle sand pit sector 1 were studied. Sedimentological $\log$ with detailed information about the grain-size and sedimentary structures of the quartz sands was made for each of these outcropping pit walls. Vertical logs were created according to the principles of sedimentological research - each depositional serie in the section was documented in the field and series with similar origin and structure were described as different packages.

Data about the grain size of the deposits were obtained from previous researches in the Bāle sand pits $[1 ; 2 ; 5]$, but during geological logging in the field it has been evaluated approximately. 
In the Bāle sand pit sector 2 one outcropping wall was documented (Fig.3). Sedimentological logs weren't made for this wall.

The interpretation of the sedimentary environment was done using the new data from the field work in July 2012, as well as thedata from the previous studies and literature.

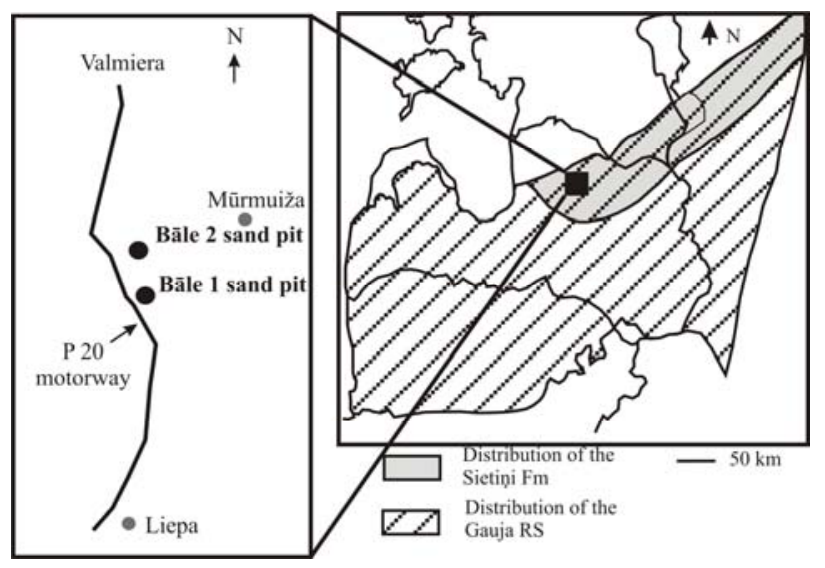

Fig. 3. Location of the Bāle quartz sand pit sectors 1 and 2.

\section{RESULTS AND DISCUSSION}

\section{A. Results of field studies of the Middle Devonian quartz sand deposits in Latvia}

The geological structure of the Devonian quartz sand beds in Latvia is relatively simple. Quartz sand units within the Sietini Fm usually are 10-15 meters thick (but can vary between 825 meters) laterally continuous sand bodies with parallel lamination and various kinds of cross-stratification. The thickness of individual cross-beds usually varies from 0.2 to $1 \mathrm{~m}$. Sandstone is mostly fine to medium grained and in places with a significant amount of clay fractions. Coarse-grained sand and gravel to pebble size quartz particles and clay clasts of various sizes are widespread in these deposits as well.

Composition and sedimentary structures of quartz sands in the Bāle sand pit sector 1 and sector 2 are studied in details and described further.

\section{Bāle sand pit sector 1}

Composition of the deposits of the Sietini Fm in the Bāle 1 sand pit varies from fine-grained to coarse-grained weakly cemented white to pale gray sandstones, in places with gravel size interlayers and quartz pebbles up to $3 \mathrm{~cm}$ in diameter.

Composition and sedimentary structures are analyzed in 8 outcropping walls (Fig.4).

Package 1 (approximately two meters up from the water level) is composed of poorly sorted material. Although particle size mostly varies from fine to medium grained sand, clastic material in the wall No 5 is poorly sorted, fine-grained sand to gravel (Fig. 5). Trough cross-beds dominate there and in lots of places the primary structure of deposits has been deformed. The thickness of individual cross-beds varies from 0.2 to $0.6 \mathrm{~m}$. This lower package is not present in all studied walls.

Package 1a is the upper part of package 1 represented by coarse to medium-grained planar-stratified and low angle cross- stratified sandstone. The thickness of individual cross beds varies from 0.25 to $1 \mathrm{~m}$. Overturned cross-stratification is common in this package of deposits.

\section{Interpretation}

Mostly planar cross-stratified beds suggest deposition of sediments in a fluvial channel by migration of $2 \mathrm{D}$ dunes. Medium size deformations in the lower part of the section suggest the possible influence of small scale slumps occurring shortly after the deposition of sediments. Small scale deformations which have disturbed the primary structure of deposits, found in the package 1a most likely have been formed due to vertical shear from escaping pore water [3].

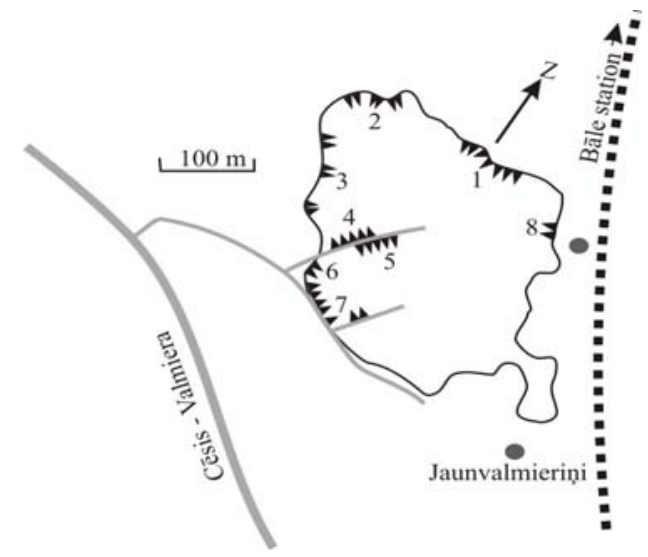

Fig. 4. Location of analysed outcrops in the Bāle sand pit, sector 1; 1-8 wall numbers [10].

Package 2 is composed of fine to coarse-grained sand material. In places this unit starts from the water level in the pit where the deformed unit is not present or lies deeper under the water level. It is composed of fine to medium-grained, in places coarse-grained sandstones with mostly planar cross-stratified, but in wall 5 and 7 (Fig.5) trough cross-stratified structure. Thickness of individual cross-beds vary from some centimeters to about $0.7-0.8 \mathrm{~m}$.

\section{Interpretation}

Trough and planar cross-stratified beds suggest deposition of sediments in a fluvial channel by migration of $2 \mathrm{D}$ and $3 \mathrm{D}$ dunes [5].

Package 3 is characterized by poorly sorted, fine to coarsegrained sandstones with mica drapes and clay clasts. The majority of succession is medium to coarse-grained sandstones with thickness of individual cross-beds $0.2-0.3 \mathrm{~m}$ with exception in the wall No 4 (Fig. 5), where the thickness of individual beds reaches $0.8 \mathrm{~m}$. Sandstones are usually trough cross-stratified, in places with small scale deformations.

\section{Interpretation}

Dominant trough cross-stratified structures indicate that the sediments were deposited in fluvial settings by migration of $3 \mathrm{D}$ dunes. Presence of mica drapes suggests the influence of tidal processes on sedimentation [3]. Small-scale deformations most likely have been formed due to vertical shear from escaping pore water. 


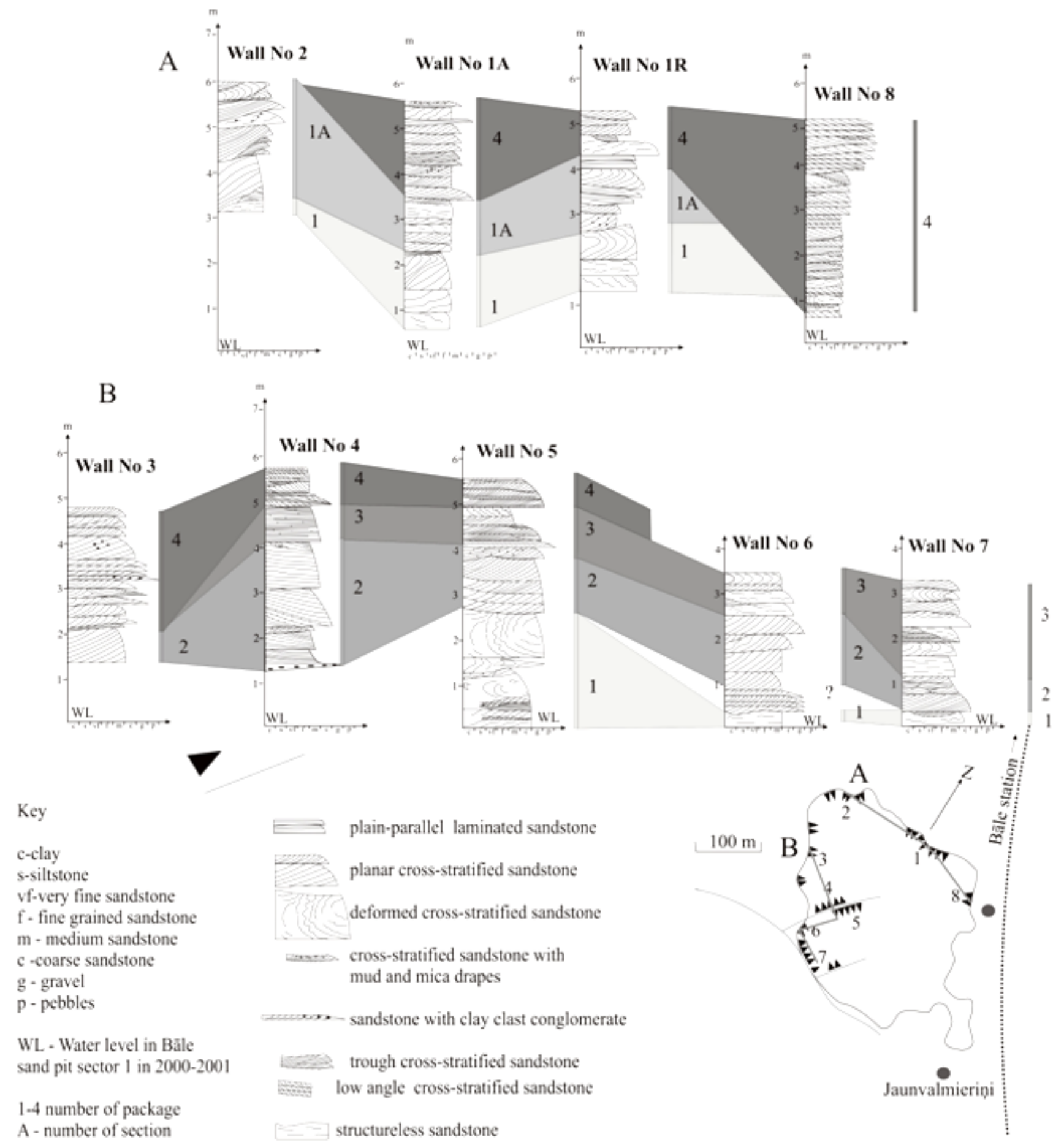

Fig. 5. Sedimentary logs of quartzose sandstones outcropping in the walls of the Bāle sand pit sector 1.

Package 4 is composed of fine to medium-grained sandstones with thickness of individual cross-beds 0.1-0.2 m. Sandstones are mostly through cross-stratified. Quartz pebbles and clay clast conglomerate are common in this part of geological section. In places small-scale deformation occurs. In general the thickness of individual cross-beds becomes smaller upwards.

\section{Interpretation}

Trough cross-stratification, rather small thickness of individual cross-beds and presence of quartz pebbles suggest deposition of this sandstone by migration of $3 \mathrm{D}$ dunes in a fluvial channel [3]. Decrease of thickness of cross-beds upwards indicates that channels gradually became shallower.

A significant characteristic in this site is that the sand material is poorly-sorted in the lowermost and in the uppermost parts of the section. The sandstones from the 
middle part of the section in most places are rather well sorted. Measurements of the dip of the cross strata clearly show deposition of sediments in south and south-west directed palaeocurrents. Results of measurements mostly vary between 165 and $195^{\circ}$ in the walls No 3 and $8,165-225^{\circ}$ in the wall 7 and $195-255^{\circ}$ in the walls No 1-2 and 4-6.

\section{Bāle sand pit sector 2}

In Bāle sand pit sector 2, which is situated few kilometers towards north from the sector 1, light gray, almost snowwhite, mostly fine and medium-grained sandstones are exposed. In this location deposits quite often contain coarse grained sandy material and gravel, but in rare cases also quartz pebbles, and that is similar to deposits occurring in the Bāle 1 sand pit. Grain-size analysis shows that fractions of $0.125-0.63$ mm make $91 \%$ of the total mass of the deposits of the Sietini Fm in the Bāle II pit. The sandstone is moderately sorted, with the sorting degree of 0.61 [9]. However, sorting changes from very good to poor, and also in pit walls it is seen that rather homogenous, well-sorted sandstone alternates with poorlysorted sandy material with large amount of gravel admixture [6]. In previous studies by K. Tovmasjana and others four packages of deposits have been divided in the northern wall of the pit [6]. The packages are overlaying each other and dipping slightly towards the south.

Package 1 consists of thin $15-20 \mathrm{~cm}$ cross-stratified sandstone beds, where the sand material is fine to coarse grained and poorly sorted. The measurements of the dip of the cross strata show mostly southwestern and western palaecurrent direction $\left(230-282^{\circ}\right)$.

\section{Interpretation}

The dominance of relatively thin trough cross-stratified sandstone and the composition of the deposits indicate sedimentation due to migration of $3-\mathrm{D}$ dunes from traction currents [6].

Package 2 which is deposited next is slightly thinner and consists of thicker cross-stratified sets. In this unit mud clasts and quartz gravel and pebble-size grains are common. The measurements of the dip of the cross strata show deposition with palaeocurrents flowing towards south and south-west $\left(170-210^{\circ}\right)$.

\section{Interpretation}

Poorly sorted texture of the deposits and the abundance of mud clasts and pebble-size quartz grains indicate deposition in fluvial channels [6].

Package 3 overlays the previous described, consists of superimposed cross-stratified units with gently inclined master bedding surfaces. The deformations are present in this unit. The palaeocurrent directions are towards the south and southeast $\left(160-201^{\circ}\right)$

\section{Interpretation}

The overall inclined master bedding surfaces with superimposed relatively thick cross-stratified units indicate deposition by migration of bars in fluvial channels [6].

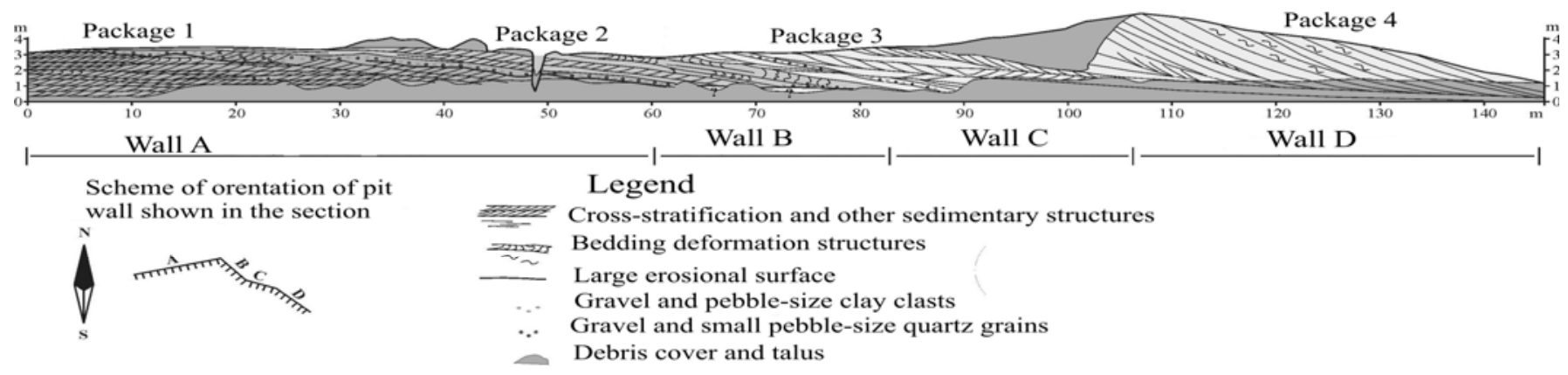

Fig. 6. Composition and structure of quartz sands in Bāle sand pit sector 2 [6].

Package 4 is characterized by about $75 \mathrm{~m}$ of slightly inclined sandstone bodies, the architecture of which significantly varies laterally. The cross-beds become thicker in downcurrent direction. Upcurrent deposits consist of crossstratified sandstones with slightly dipping master bedding, but downcurrent (more towards south) deposits are characterized by steeply dipping master bedding surfaces. Deformations are abundant especially in the steeply dipping deposits.

Sandstone packages are not only inclined in southwards (basinwards) direction, but also have erosional boundaries.

\section{Interpretation}

The composition of the deposits, the inclined master bedding surfaces and the dip of cross-beds indicate deposition of this package in migrating bars of the fluvial channels [6].

\section{A. Depositional environment of the Sietini Formation}

According to the interpretations of P. Plink-Björklund and A. Pontén [3] the lower, sandy, rather coarse-grained part of the Sietini Fm corresponds to maximum progradation of the Middle Devonian delta system with a large area of tidally reworked facies. They suggest [3] that in the Gauja time sediments were deposited in tide-influenced delta environment and the lower part of the Sietini Fm consists of sub-tidal bars overlain by tide influenced channels, and fine to coarsegrained quartz sands of the Sietini Fm were deposited on the delta plain.

Data from the Bāle sand pit sector 1 shows quartz sand deposition by the migration of $2 \mathrm{D}$ and $3 \mathrm{D}$ dunes in fluvial channels. Rather coarse material and quartz pebbles in sediments indicate high current velocity during deposition. Small to medium scale deformations found in deposits could 
be formed because of the small-scale slump processes, but in most cases small-scale deformed cross-stratified units have been most likely deposited by traction currents and deformed by vertical shear from escaping pore water. Data about the shape of sand bodies and internal structure from Bāle sand pit sector 2 [6] suggest the deposition of quartz sands in fluvial channel and also shows deposition as prograding bar.

P. Plink-Björklund and A. Pontén [3] suggest that there was a very shallow water depth offshore from the delta at that time. Direct signs of tidal influence during formation of Sietini Fm quartz sand deposits in Bāle 1 and Bāle 2 sand pits are rarely found. However, presence of mica drapes in sediments (in Bāle sand pit sector 1 package 3 ) and coarser material on the top of stratified bodies may indicate the influence of the tides.

Measurements of cross-stratification show deposition of quartz sands in palaeocurrents flowing mostly towards the south and southwest, which confirms the data of previous workers $[1 ; 3]$.

The new data obtained during fieldwork in the Bāle sand pits confirms the development of the delta plain during the beginning of deposition of the Gauja RS as suggested earlier by P. Plink-Björklund and A. Pontén [3; 4], however, according to our data the influence of tidal processes on sedimentation for this time seems to be insignificant.

\section{CONCLUSIONS}

Quartz sand deposits of the Devonian Gauja RS, Sietini Fm are similar by their dominant bed architecture, textures and structures, which eases their extraction and use. However, sand material is poorly sorted in many places, and it decreases the quality of it as a commercial mineral.

The Sietini Fm is dominated by fine to coarse-grained planar cross-stratified and trough cross-stratified units with quartz pebbles and clay clasts suggesting the deposition of sands in traction currents in fluvial channels.

Trough cross-stratified beds with mica drapes in the package No 3 in Bāle sand pit sector 1 most likely indicates the influence of the tides during some periods of deposition, however, it was not significant.

Composition, sedimentary structures and bed architecture together with the lack of reliable evidence of the significant tidal influence supports the previous interpretations by P. Plink-Björklund and Anna Pontén about the deposition of quartz sands in distributary channels $[3 ; 4 ; 6]$.

The information about the sedimentary environment of quartz sands helps predicting the distribution and structure of commercially useful sand bodies more precisely.

\section{REFERENCES}

[1] Kurshs, V. Devonian terrigenous deposition in the Main Devonian field. Riga, Zinatne, (in Russian), 1992.

[2] Kurshs, V. Lithology and mineral deposits of the clastic Devonian sequence of the Main Field, Riga, Zinatne, (in Russian), 1975.

[3] Pontén, A., Plink-Björklund, P. Depositional environments in an extensive tide - influenced delta plain, Devonian Baltic Basin. Sedimentology, 2007, N $\quad 54, \quad$ p. $\quad 969-1006$. http://dx.doi.org/10.1111/j.1365-3091.2007.00869.x

[4] Pontén, A., Plink-Björklund, P. Regressive to transgressive transits reflected in tidal bars, Middle Devonian Baltic Basin. Sedimentary Geology, 2009, $\quad$ N $218, \quad$ p. $48-60$ http://dx.doi.org/10.1016/j.sedgeo.2009.04.003

[5] Stinkule, A., Stinkulis, G. Quartz sands. In: Mineral resources of Latvia, Riga, University of Latvia (in Latvian), 2013. p. 46-56.

[6] Tovmasjana, K., Stinkulis, G.., Karušs, J., Sandstones of the Devonian Sietini Formation and their sedimentary environment in the Bāle II sand pit. The Eighth Baltic Stratigraphical Conference - Post-conference Field Excursion Guidebook, University of Latvia, Riga, 2011. p. 33-36.

[7] Kleesment, A., Mark-Kurik, E. Devonian. In: Geology and mineral resources of Estonia. Estonian Academy Publishers, Tallinn, 1997. p. 107-123.

[8] Lukševičs, E., Stinkulis, G., Mūrnieks, A., Popovs, K. Geological evolution of the Baltic Artesian Basin. In: Higlights of groundwater research in Baltic Artesian Basin, Rīga, University of Latvia, 2012, p. 752.

[9] McManus, J. Grain size determination and interpretation. In: Techniques in Sedimentology, Blackwell Science, Oxford, 1988. p. 63-85.

[10] Tovmasjana, K., Sietinu svītas smilšakmeņu tekstūras un veidošanās apstāklli Bāles karjerā. Master thesis: Riga, University of Latvia.

Daiga Blākse received a Master's degree in Geology from the University of Latvia, the Faculty of Geography and Earth Sciences in 2009.

Currently she is a doctoral student at the University of Latvia, the Faculty of Geography and Earth Sciences.

Her current studies are devoted to Middle to Upper Devonian clastic deposits and their sedimentary environment.

Faculty of Geography and Earth Sciences, University of Latvia

Address: Alberta Street 10, LV-1010, Riga, Latvia

Telephone: 67332704; fax 67332704; E-mail:daiga.blake@gmail.com

Kristine Tovmasjana received a Doctoral Degree in Geology from the University of Latvia, the Faculty of Geography and Earth Sciences in 2013. She currently works as a Program Specialist for UNESCO in Paris.

Address: Place de Fontenoy 75352, Paris, 07SP, France

Telephone: +33 (0) 1456840 88; E-mail: k.tovmasyan@unesco.org

Girts Stinkulis received a Doctoral degree in Geology from the University of Latvia, the Faculty of Geography and Earth Sciences in 1998.

Since 2008 he is an Associated Professor at the University of Latvia, the Faculty of Geography and Earth Sciences.

His scientific studies are focused on carbonate and siliciclastic sedimentology, as well as distribution and origin of useful minerals of Latvia.

Faculty of Geography and Earth Sciences, University of Latvia Address: Alberta Street 10, LV-1010, Riga, Latvia

Telephone: 67333071; fax 67332704; E-mail:Girts.Stinkulis@lu.lv

Faculty of Geography and Earth Sciences, University of Latvia

Address: Alberta Street 10, LV-1010, Riga, Latvia

Telephone: 67332704; fax 67332704; E-mail: Girts.Stinkulis@lu.lv

\section{Daiga Blāķe, Kristīne Tovmasjana, Ģirts Stinkulis. Latvijas devona kvarca smilšu veidošanās apstākḷi}

Šajā rakstā apkopota informācija no iepriekšējiem pētîjumiem, kas īsi aplūko devona kvarca smilšaino nogulumu veidošanās apstākḷus, kā arī izklāstīti jauni dati, kas iegūti lauka pētījumos Bāle 1 un Bāle 2 smilšu atradnēs. Devona kvarca smiltsieži Latvijā (arī DA Igaunijā un R Krievijā) ir sastopami vidusdevona Gaujas reǵionālā stāva Sietinu svītā. Pašlaik kvarca smiltis tiek iegūtas Bāle 2 atradnē. Derīgo slāṇkopu veido smalk- līdz rupjgraudaini balti līdz gaiši pelēki smilšakmeṇi, kas vietām satur māla saveltṇus un kvarca oḷus. Materiāls ir vidēji līdz vāji šķirots. Kvarca saturs smilšakmeņos sasniedz līdz 97\% un kaitīgais $\mathrm{Fe}_{2} \mathrm{O}_{3}$ piemaisījums sastāda 0,16-0,17\%.

Pētījuma mērḳis bija interpretēt devona kvarca smilšakmeņu veidošanās apstākḷıs, kā arī apkopot iepriekšējos datus par šo nogulumu sastāvu, uzbūvi un veidošanos. Pētījuma laikā tika apkopota pieejamā literatūra un iepriekšējie pētījumi par Sietiṇu svītas kvarca smilšu sastāvu, uzbūvi un sedimentācijas tekstūrām, kā arī tika veikti lauka pētījumi karjeros Bāle 1 un Bāle 2 . 
Noskaidrots, ka kvarca smilšu iegulām ir relatīvi vienkārša uzbūve, kas atvieglo to ieguvi, tomēr smilšu kvalitāti samazina to samērā vājā šķirotība un kaitīgo minerālu piejaukums. Slānnkopas pētījumi Bāles kvarca smilšu atradnes 1. un 2. sektorā norāda uz smilšu izgulsnēšanos deltas kanālos un sērēs ar nelielu plūdmaiņu ietekmi uz sedimentāciju. Māla saveltņu un kvarca oḷu klātbūtne Sietiņu svītas nogulumos norāda uz ievērojamu fluviālu apstākḷu ietekmi kvarca smilšu izgulsnēšanās laikā, savukārt, nepārprotamu un skaidru plūdmaiņu tekstūru trūkums (dažviet gan novērotas vizlas kārtiņas uz slīpslāņojuma) Sietiņu svītas nogulumos pētîtajā teritorijā liecina, ka šie apstākḷi nav bijuši dominējošie. Precīza sedimentolog̣isko datu interpretācija ir svarīga derīgās slāṇķopas kvalitātes un izplatības prognozēšanā kvarca smilšu ieguves nolūkos.

Дайга Блаке, Кристине Товмасян, Гиртс Стинкулис. Условия образования девонских кварцевых песков Латвии.

Целью статьи является интерпретация условий образования девонских кварцевых песков, а также обобщение материалов предыдущих исследований этих отложений.

Кварцевые пески девонского возраста в Латвии, а также на ЮВ Эстонии и северо-западе России встречаются в сиетиньской свите (средний девон, гауйский региональный ярус). В настоящее время кварцевые пески добывают в месторождении Бале 2 . Полезную толщу образуют тонко-грубозернистые, белые до светлосерых песчаники, местами содержащие катуны глины и гальку кварца. Материал является от средне до плохо сортированного. Содержание кварца в песчаниках 97\% и вредная примесь $\mathrm{Fe}_{2} \mathrm{O}_{3}$ образует $0,16-0,17 \%$.

Седиментологические исследования песчаной толщи в секторе 1 и 2 месторождения Бале показывают сравнительно простое строение залежей кварцевых песков, облегчающее их добычу, но качество песка ухудшает низкая степень сортированности и примесь тяжелых минералов. Исследование строения толщи указывает на образование песчаной толщи в дельтовых каналах и барах с небольшим влиянием приливно-отливных процессов. Катуны глины и галька кварца в отложениях сиетиньской свиты указывают на существенную роль флювиальных процессов во время осадконакопления, и отсутствие ясных признаков приливно-отливных текстур (хотя местами встречаются прослойки слюды на косых слойках), что свидетельствует о том, что приливно-отливные процессы не являлись доминирующими на исследованной территории.

Точная интерпретация седиментологических данных важна для прогнозирования качества и закономерностей распространения полезной толщи с целью добычи кварцевых песков. 